Bangladesh J. Bot. 48(4): 1099-1106, 2019 (December)

\title{
MOLECULAR CHARACTERIZATION BASED ON CHLOROPLAST (trnL-F) DNA SEQUENCE OF THE APPLE GENOTYPES IN ARDAHAN/TURKEY
}

\author{
Emre Sevindik ${ }^{*}, Z_{\text {Ehra TuĞba Murathan }}{ }^{1}$, Sümeyye Filiz and Kübra YalçIn \\ Department of Agricultural Biotechnology, Faculty of Agriculture, \\ Adnan Menderes University, South Campus, Cakmar, Aydin, Turkey
}

Keywords: Apple, cpDNA, trnL-F, Genetic diversity

\begin{abstract}
Genetic diversity among Turkish apple genotypes in Ardahan province was conducted based on cpDNA trnL-F sequences. Apple genotypes were plotted on a phylogenetic tree where Pyrus $x$ bretschneideri was used as the outgroup. The plant samples were collected from different locations and genomic DNA was isolated from healthy and green leaves. For sequence in $t r n \mathrm{~L}-\mathrm{F}$ region $t r n \mathrm{Le}$ and $t r n \mathrm{Ff}$ primers were used. Later obtained DNA sequences were edited using the BioEdit and FinchTV. Sequencing data were analyzed using MEGA 6.0 software. Neighbor joining and bootstrap trees were constructed in order to verify the relationships among the apple genotypes. Phylogenetic tree consisted of two clades. The divergence values of trnL-F sequences differed between 0.000 and 0.005. Average nucleotide composition was $38.3 \mathrm{~T}, 14.9 \mathrm{C}$, $31.9 \mathrm{~A}$ and $14.9 \% \mathrm{G}$. The phylogenetic tree constructed based on $t r n \mathrm{~L}-\mathrm{F}$ region sequences was nearly parallel to prior phylogenetic studies on apple genotypes.
\end{abstract}

\section{Introduction}

Anatolia is accepted as the homeland of many wild, wild edible and cultivated fruit species in addition to harboring rich apple genetic resources including mostly historical cultivars selected by humans among wild populations for centuries (Çelik et al. 2018). Apple (Malus L.) belongs to Rosaceae is a widespread genus in the world with many species (Dziubiak 2004, Ercisli 2004). Four origin centers for apples were reported, including East Asia, Central Asia, East Asia-Europe and North America. Turkey belongs to East Asia-Europe origin center and has considerable diversity (Uzun et al. 2016). Apple can easily grow in many places due to the wide area and the climate tolerance (Bulantekin and Kuşcu 2017) and a good source of phenolic compounds and antioxidants for human diet and health (Wolfe et al. 2003, Wolfe and Liu 2003). The preference criteria that consumers pay the greatest attention are its bright and red colour. Under the light of previous studies, it was detected that red vegetables and fruits have more antioxidants compared to green ones. It was also detected that in addition to having more antioxidants, red fruits also have more phenolic compounds (Neill et al. 2002a,b, Neill and Gould 2003, Hughes et al. 2005, Shao et al. 2007).

Genetic markers give an insight in the amount and distribution of genetic variation within populations (Bolovic et al. 2013). By using DNA sequence data, differences and the genetic relationships of living things have been reported through the latest developments in molecular biology (Weiguo et al. 2005). Chloroplast DNA (cpDNA) sequence variations have been widely utilized for detecting species relationships between angiosperms and other plants. Hence, it has been widely used in phylogenetic assessments. Low rate of change of these molecules is restrictive in in-species degree (Taberlat et al. 1991, Türktaş et al. 2012). Chloroplast DNA (cpDNA) has many useful noncoding regions in terms of phylogenetics. Due to its phylogenetic

*Author for correspondence: <ph.d-emre@hotmail.com>. ${ }^{1}$ Food Engineering Department, Ardahan University, Ardahan, Turkey. 
value, the region of tRNA $(\operatorname{trn} \mathrm{T}-\operatorname{trn} \mathrm{F})$ has been extensively studied. Its intergenic space takes place between $t r n \mathrm{~L}$ (UAA) 3'exon and $\operatorname{trn} \mathrm{F}$ (GAA) gene (Taberlat et al. 1991, Gielly and Taberlat 1994, Gielly and Taberlat 1996, Liu et al. 2005). There are two protected exon areas in trnL gene (Fig. 1).The aim of this study was to conduct molecular characterization of local apple cultivars, which are distributed in the ecological conditions of Ardahan, through the use of $t r n \mathrm{~L}-\mathrm{F}$ region in chloroplast DNA.

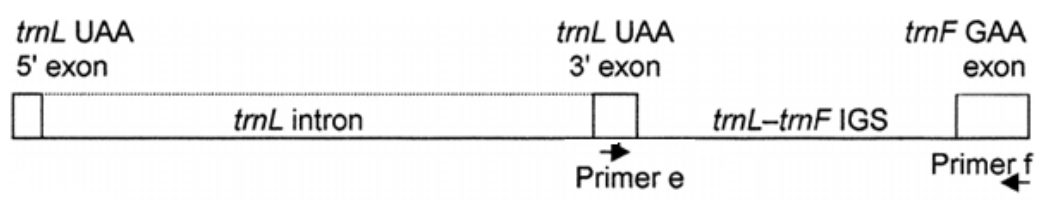

Fig. 1. cpDNAtrnL-F region (Pirie et.al. 2007).

\section{Materials and Methods}

Apple genotypes used in the study were collected from certain regions in Ardahan/Turkey between July and August, 2015 (Fig. 2). Total genomic DNA samples were extracted using DNA Plant Kit (Gene Mark). The genomic DNA samples were stored at $-20{ }^{\circ} \mathrm{C}$.

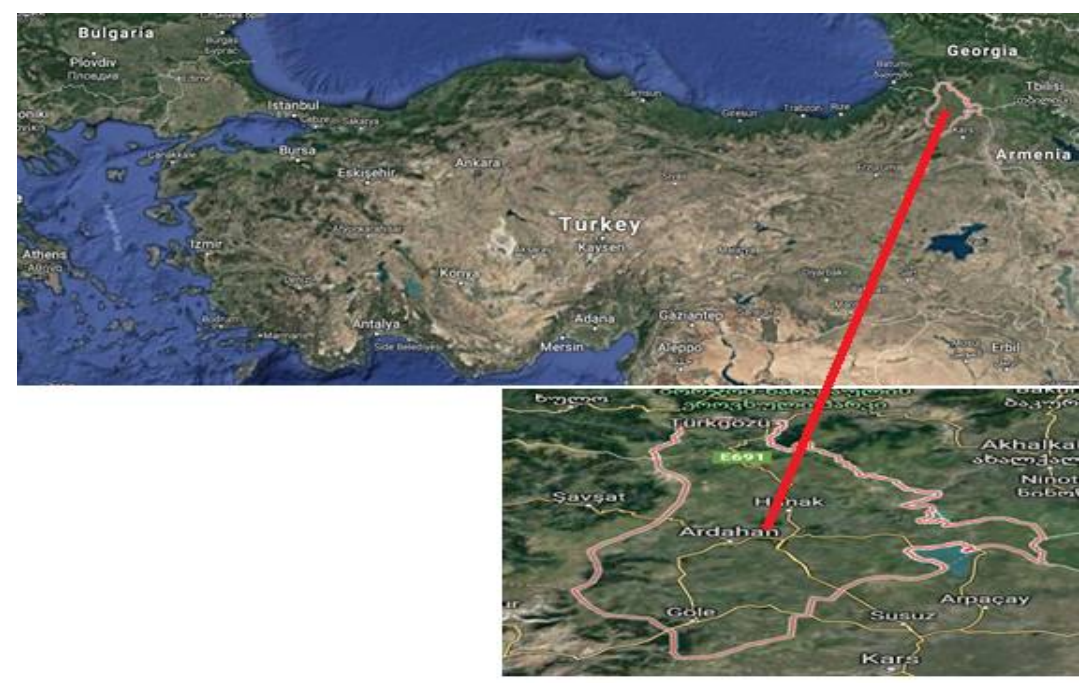

Fig. 2. Location of the Ardahan province. The upper map shows the location of Ardahan within Turkey while the enlarged region of Ardahan is shown in the lower map. The maps were obtained from Google Maps (maps.google.com).

Double-stranded DNA of the complete trnL-F regions in each genomic DNA sample were amplified. Amplification of the whole trnL-F molecular marker analyzed in this study belongs to the cpDNA. PCR amplifications of trnL-F cpDNA were performed using the primers designed by Taberlet et al. (1991) (Table 1) for all taxa included in this work. The amplification process was carried out in $25 \mu \mathrm{l}$ of PCR reaction volume. Each PCR reaction contained $2.0 \mu 1$ of total genomic DNA, $15 \mu \mathrm{l}$ of dd $\mathrm{H}_{2} \mathrm{O}, 5 \mu \mathrm{l}$ master mix (PCR buffer, $\mathrm{MgCl}_{2}$, dNTP, Taq DNA polymerase), $1 \mu \mathrm{l}$ for $t r n \mathrm{Le}$ and $1 \mu \mathrm{l}$ for $t r n \mathrm{Ff}$ primers and $1 \mu \mathrm{l}$ of DMSO. Table 2 shows trnL-F PCR cycles with their respective conditions. Gel electrophoresis in $0.8 \%$ agarose gel run in 1.0X TBE (Tris-Boric EDTA) buffer was used to size fraction at amplicons. Subsequently gels were stained with ethidium bromide and visualized over a UV trans-illuminator. The $\operatorname{trn} \mathrm{Le}$ and $\operatorname{trn} \mathrm{Ff}$ primers were 
used both for amplification and for sequencing which were conducted at Labbiotek (İzmir, Turkey) using an ABI3130XL genetic analyzer. For each sample, forward and reverse sequencing reactions were performed and the sequences were analyzed via GenBank (NCBI) through BLASTn search. Subsequently obtained DNA sequences were edited both manually and by using BioEdit (Hall 1999), and FinchTV programs.

Table 1. cpDNA trnL-F primers used in this study with their designers.

\begin{tabular}{lll}
\hline $\begin{array}{l}\text { Primer } \\
\text { name }\end{array}$ & $\begin{array}{l}5^{\prime} \text { ' to } \text { ' }^{\prime} \text { primer } \\
\text { sequence }\end{array}$ & $\begin{array}{l}\text { Based on (the source } \\
\text { publication) }\end{array}$ \\
\hline $\begin{array}{l}\text { Forward } \\
\text { trnLe }\end{array}$ & GGTTCAAGTCCCTCTATCCC & Taberlet et al. 1991 \\
$\begin{array}{l}\text { Reverse } \\
\text { trnFf }\end{array}$ & ATTTGAACTGGTGACACGAG & Taberlet et al. 1991 \\
\hline
\end{tabular}

Table 2. Cycles and conditions of trnL-F -PCR reactions.

\begin{tabular}{llll}
\hline Pre-heating & $94^{\circ} \mathrm{C}$ & $5 \mathrm{~min}$ & 1 cycle \\
1. step & $94^{\circ} \mathrm{C}$ & $30 \mathrm{~s}$ & \\
2. step & $50^{\circ} \mathrm{C}$ & $30 \mathrm{~s}$ & \\
3. step & $72^{\circ} \mathrm{C}$ & $90 \mathrm{~s}$ & 35 cycles \\
4. step & $72^{\circ} \mathrm{C}$ & $8 \mathrm{~min}$ & 1 cycle \\
5. step & $4^{\circ} \mathrm{C}$ & $20 \mathrm{~min}$ & \\
\hline
\end{tabular}

cpDNA trnL-F sequences were aligned using ClustalW alignment software (Thompson et al. 1994). The phylogenetic tree was generated using the Neighbor joining tree (Saitou and Nei 1987) and constructed using MEGA 6.0 software (Tamura et al. 2013). The phylogenetic tree was evaluated with bootstrap test with 1000 resamplings (Felsenstein 1985). Beside Pyrus $\times$ bretschneideri (GenBank: JX122456.1) taxa was used out group in the tree obtained from NCBI.

\section{Results and Discussion}

trnL-F sequences ranged from 418 to 428 nucleotides among 13 genotypes (only apple genotypes and except for outgroup Pyrus $\times$ bretschneideri). The highest number of nucleotides for the trnL-F sequence was observed in Uruset apple and Kırmızı Safran (428 bases) while the lowest number of nucleotides for the trnL-F sequence was observed in Sobe apple (418 bases). Average nucleotide composition of trnL-F was $38.3 \mathrm{~T}, 14.9 \mathrm{C}, 31.9 \mathrm{~A}$ and $14.9 \% \mathrm{G}$. The maximum GC content $(30.2 \%)$ and the lowest AT content (69.9\%) were observed in Kurmız Safran and Uruset apple while the lowest GC content (29.3\%) and the highest AT content (70.7\%) were recorded in Limon apple (Table 3). Genetic distance method based on trnL-F set was performed with MEGA 6.0 software. The lowest distance was 0.000 while the highest distance was 0.005 (Table 4).

Neighbor joining tree was construted using $t r n \mathrm{~L}-\mathrm{F}$ sequences of apple genotypes distributed in Ardahan province, and sequences of outgroup was retrieved from NCBI (GenBank). Neighbor joining tree generated based on trnL-F sequences of the samples consists of two large clades. Clade 1 consists of Sisli Uruset, Sobe apple, Sarı Safran, Paşa apple, Şah apple, Uruset apple, Kırmızı safran, Karpuz apple, and Limon apple genotypes. (Fig. 3). Sevindik et al. (2018) reported the genetic diversity of Ardahan apple genotypes using ISSR markers. In their study, Sobe apple, Kırmızı safran, Limon apple, Uruset apple, Şah apple and Sisli uruset apple genotypes were found to be in the same clade. Uzun et al. (2016) studied the genetic relationships of Turkish apple genotypes using ISSR markers. In their study, Karanfil apple, Şah apple and Paşa apple genotypes were found to be in the same group, while Kaba apple was found in a different group. In the present 
study, these two genotypes (Şah apple and Paşa apple) were found in the clade 1, while Kaba apple and Karanfil apple were found in clade 2. Osmanoğlu (2008) revealed genetic relationships of apple genotypes collected from Ardahan/Posof region using RAPD markers. As a result of their study, Sobe apple, Sarı Safran, Kırmızı safran, Uruset apple, Kaba uruset and Paşa apple genotypes were grouped in the same clade, but Limon apple genotype was in a different clade. In clade 2 consist of

Table 3. Length and $A+T$ and $G+C$ contents of cpDNA trnL-F sequences of apple genotypes.

\begin{tabular}{llllllll}
\hline Genotypes & $\begin{array}{l}\text { cpDNA } \\
\text { trnL-F }(\mathrm{bp})\end{array}$ & $\begin{array}{l}\mathrm{A}(\%) \\
\text { content }\end{array}$ & $\begin{array}{l}\mathrm{T}(\%) \\
\text { content }\end{array}$ & $\begin{array}{l}\mathrm{G}(\%) \\
\text { content }\end{array}$ & $\begin{array}{l}\mathrm{C}(\%) \\
\text { content }\end{array}$ & $\begin{array}{l}\text { A+T }(\%) \\
\text { content }\end{array}$ & $\begin{array}{l}\mathrm{G}+\mathrm{C}(\%) \\
\text { content }\end{array}$ \\
\hline Kaba apple & 424 & 31.8 & 38.4 & 14.9 & 14.9 & 70.2 & 29.8 \\
Kaba Uruset & 423 & 31.7 & 38.5 & 14.7 & 15.1 & 70.2 & 29.8 \\
Kaburga apple & 427 & 32.6 & 37.9 & 14.5 & 15.0 & 70.5 & 29.5 \\
Karanfil apple & 426 & 31.9 & 38.0 & 15.0 & 15.0 & 69.9 & 30 \\
Karpuz apple & 427 & 31.6 & 38.4 & 15.0 & 15.0 & 70 & 30 \\
Kırmız1 Safran & 428 & 31.8 & 38.1 & 15.0 & 15.2 & 69.9 & 30.2 \\
Limon apple & 420 & 31.9 & 38.8 & 14.5 & 14.8 & 70.7 & 29.3 \\
Paşa apple & 426 & 31.9 & 38.3 & 15.0 & 14.8 & 70.2 & 29.8 \\
Şah apple & 424 & 31.8 & 38.2 & 15.1 & 14.9 & 70 & 30 \\
Sarı Safran & 424 & 31.8 & 38.4 & 15.1 & 14.6 & 70.2 & 29.7 \\
Sisli Uruset & 426 & 31.9 & 38.3 & 15.0 & 14.8 & 70.2 & 29.8 \\
Sobe apple & 418 & 31.8 & 38.8 & 14.6 & 14.8 & 70.6 & 29.4 \\
Uruset apple & 428 & 31.8 & 38.1 & 15.0 & 15.2 & 69.9 & 30.2 \\
Average & 424.7 & 31.9 & 38.3 & 14.9 & 14.9 & 70.2 & 29.8 \\
\hline
\end{tabular}

Karanfil apple, Kaburga apple, Kaba apple and Kaba Uruset genotypes formed a group, (Fig. 3). Sevindik et al. (2018) identified Kaburga apple and Kaba apple genotypes in a clade while Karanfil apple genotype was determined different clade. Osmanoğlu (2008) identified Kaburga apple, and Kaba Uruset genotypes in one clade, and Kaba apple genotype in another clade. In the phylogenetic tree, Pyrus $x$ bretschneideri species selected as outgroup constituted a separate group from apple genotypes (Fig. 3). There are several molecular studies among the previous studies carried out with the use of Apple genotypes. Markers such as RAPD, SSR, nrDNA ITS, cpDNA matK, $a t p \mathrm{~B}$, and $a t p \mathrm{~B}-r b c \mathrm{~L}$ were used in these studies (Savolainen et al. 1995, Hokanson et al. 1998, Robinson et al. 2001, Kaya et al. 2015, Mahmood et al. 2016, Daler et al. 2017). Daler et al. (2017) specified the relationship degree of genotypes using RAPD molecular technique on 6 apple genotypes obtained from Isparta/Eğirdir Fruit Research Institute Directorate's collection. Kaya et al. (2015) carried out molecular analysis of Apple genotypes collected from Van province, through using RAPD markers. Creating a dendrogram, the similarity index between genotypes was revealed. Robinson et al. (2001) revealed the phylogenetic relationships between apple species by carrying out sequence analysis of ITS of seed DNA and matK areas of chloroplast DNA 29 apple species. Mahmood et al. (2016) revealed genetic relationships of varieties by carrying out sequence analysis of apple varieties' atpB gene areas, which they chose from Pakistan. Savolainen et al. (1995) revealed chloroplast variations by carrying ou $\mathrm{t} a t p \mathrm{~B}-r b c \mathrm{~L}$ 


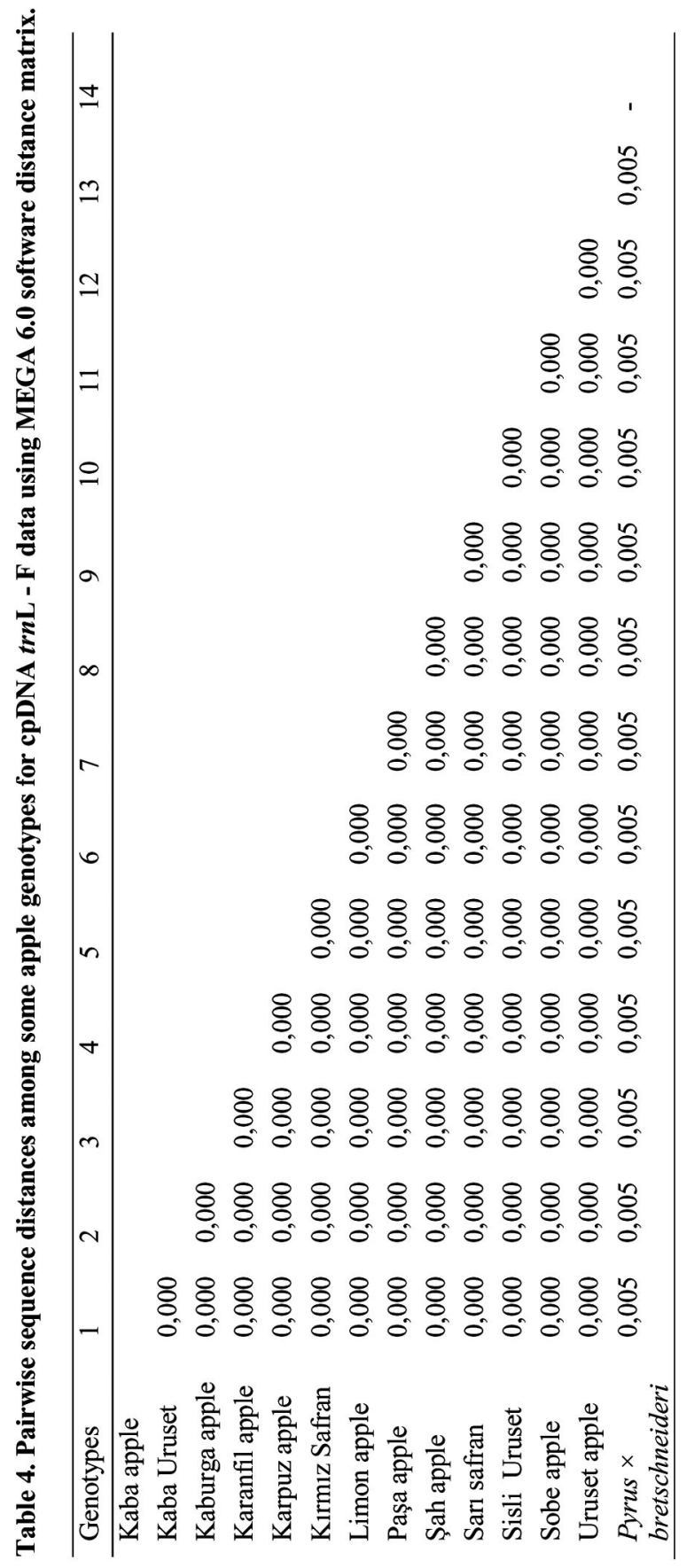


sequence analysis of 55 apple cultivars, and 15 of them were wild apples. Hokanson et al. (1998) explained genetic relationships of Malus $\times$ domestica populations by using SSR (microsatellite) markers. In conclusion, this study has revealed molecular characterization and genetic relationships of apple genotypes distributed in Ardahan province by using chloroplast

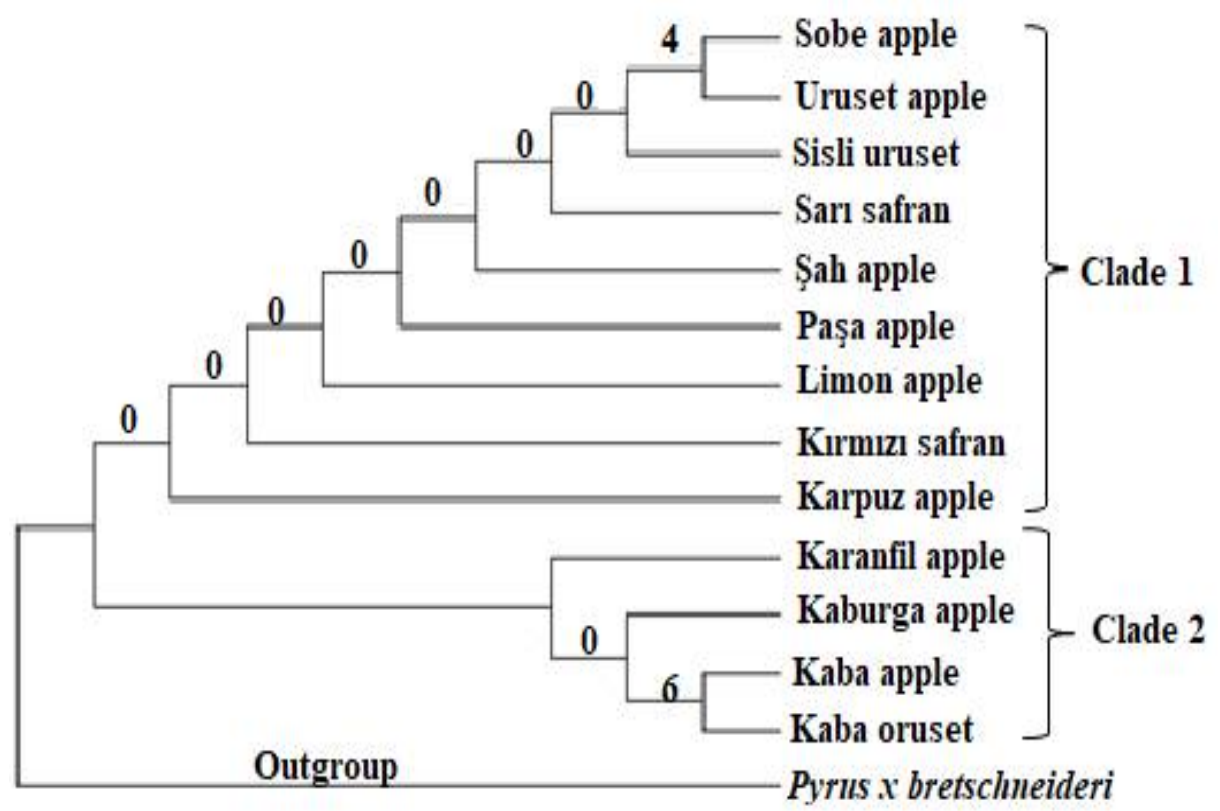

Fig. 3. The Neighbor joining tree with bootstrap values (1000 replicates) generated using cpDNA trnL-F sequences of apple genotypes and therelated sequence retrieved from NCBI GenBank (Pyrus $x$ bretschneideri (GenBank: JX122456.1).

trnL-F sequences. The obtained findings can be a reference for molecular studies with different markers and different gene sequences to be carried out in the future. The results may also be utilized for the correct identification of the apple genotypes studied along with their close relatives.

\section{References}

Bojović S, Heizmann P, Dražić D, Kovačević D, Marin P, Popović Z, Matic R, and Jurc M 2013. Diversity of Fraxinus ornus from Serbia and Montenegro as revealed by RAPDs. Genetika. 45(1): 51-62.

Bulantekin Ö, and Kuşçu A 2017. Elmada Bulunan Fitokimyasallar ve Diğer Zengin Bileşenlerin İnsan Sağlığına Yararları. Meyve Bilimi. 1:213-218.

Celik F, Gundogdu M, Ercisli S, K a k i B, Berk S, Ilhan G and Sagbas HI 2018. Variation in organic acid, sugar and phenolic compounds in fruits of historical apple cultivars. Not Bot. Hort. Agrobo. 46(2): 622629.

Daler S, Aşkın MA and Karakurt Y 2017. Bazı Birbirine Benzer apple (Malus domestica L.) Genotiplerinde Pomolojik ve Moleküler Yöntemlerle Genetik Akrabalık Derecelerinin Tespiti. Süleyman Demirel Üniversitesi Fen Bilimleri Enstitüsü Dergisi. 21(2): 444-452.

Dziubiak M 2004. Collection of the genus Malus Mill. In the botanical garden of the Polish Academy of Sciences in Warsaw. J. Fruit Ornam. Plant. Res. 12: 121-128. 
Ercişli S 2004. A short review of the fruit germplasm resources of Turkey. Genet. Resour. Crop Ev. 51(4): 419-435.

Felsenstein J 1985. Confidence Limitson Phylogenies : An Approach using the Bootstrap. Evoluation 39:783-791.

Gielly L and Taberlet P 1994. The use of chloroplast DNA to resolce plant phylogenies: Non-coding versus $r b c L$ sequences. Mol. Biol. Evol. 11(5): 769-777.

Gielly L and Taberlet P 1996. A phylogeny of the European gentians inferred from chloroplast trnL (UAA) intron sequences. Bot. J. Linn Soc. 120: 57-75.

Hall TA 1999. Bioedit: A user-friendly biological sequence alignment editor and analyses program for Windows 95/98/NT. Nucleic Acids Symp. 41: 95-98.

Hokanson SC, Szewc-McFadden AK, Lamboy WF and McFerson JR 1998. Microsatellite (SSR) markers reveal genetic identities, genetic diversity and relationships in a Malus $\times$ domestica Borkh. core subset collection. Theor. Appl. Genet. 97(5-6): 671-683.

Hughes NM, Neufeld HS and Burkey KO 2005. Functional role of anthocyanins in high-light winter leaves of the evergreen herb Galax urceolata. New Phytol. 168: 575-587.

Kaya T, Balta F and Şensoy S 2015. Fruit quality parameters and molecular analysis of apple germplasm resources from Van Lake Basin, Turkey. Turk. J. Agric. For. 39(6): 864-875.

Liu Q, Ge S, Tang H, Zhang X, Zhu G and Lu B-R 2005. Phylogenetic relationships in Elymus (Poaceae: Triticeae) based on the nuclear ricosomal internal transcribed spacer and chloroplast $\operatorname{trn} \mathrm{L}-\mathrm{F}$ sequences. New Phytol. 170: 411-420.

Mahmood T, Bakht NU and Aziz E 2016. Computational analysis of atpB gene promoter from different Pakistani apple varieties. Comput Biol. Chem. 64: 1-8.

Neill S, Gould KS, Kilmartin PA, Mitchell KA and Markham KR 2002a. Antioxidant activities of red versus green leaves in Elatostema rugosum. Plant Cell Environ. 25: 539-547.

Neill S, Gould KS, Kilmartin PA, Mitchell KA, and Markham KR 2002b. Antioxidant capacities of green and cyanic leaves in the sun species Quintinia serrata. Funct Plant Biol. 29: 1437-1443.

Neill SO and Gould KS 2003. Anthocyanins in leaves: light attenuators or antioxidants? Funct Plant Biol. 30: 865-873.

Osmanoğlu A 2008. Posof (Ardahan) yöresi elma genetik kaynaklarının fenolojik, morfolojik, pomolojik ve moleküler tanımlanması. Yüzüncü Y1l Üniversitesi, Fen Bilimleri Enstitüsü, Doktora Tezi. pp. 133

Pirie DM, Vargas BMP, Botermans M, Bakker TF and Chatrou WL 2007. Ancient paralogy in the cpDNA trnL-F region in Annonaceae: Implications for PlantMolecular Systematics. Am. J. Bot. 94(6): 10031016

Robinson JP, Harris SA and Juniper BE 2001. Taxonomy of the genus Malus Mill.(Rosaceae) with emphasis on the cultivated apple, Malus domestica Borkh. Plant Syst. Evol. 226(1-2): 35-58.

Saitou N and Nei M 1987. The neighbor-joining method: A new method for reconstruct in phylogenetic trees. Mol. Phylogenet Evol. 4(4): 406-425.

Savolainen V, Corbaz R, Moncousin C, Spichiger R and Manen JF 1995. Chloroplast DNA variation and parentage analysis in 55 apples. Theor. Appl. Genet. 90(7-8): 1138-1141.

Sevindik E, Uysal H, and Murathan ZT 2018. Genetic diversity based on ISSR markers of apple genotypes in Ardahan/Turkey. Not Sci. Biol. 10(4): 554-558.

Shao L, Shu Z, Sun SH, Peng CH, Wang X and Lin ZH 2007. Antioxidation of anthocyanins in photosynthesis under high temperature stress. J Integr Plant Biol. 49(9): 1341-1351.

Taberlet PT, Gielly L, Pautou G and Bouvet J 1991. Universal primers for amplification of three non-coding regions of chloroplast DNA. Plant Mol. Biol. 17(5): 1105-1109.

Tamura K, Stecher G, Peterson D, Filipski A and Kumar S 2013. MEGA 6: Molecular evolutionary genetics analysis version 6.0. Mol. Biol. Evol. 30(12): 2725-2729.

Thompson JD, Higgins DG and Gibson TJ 1994. CLUSTALW : Improving the sensitivity of progressive multiple sequence alignment through sequence weighting, position-specific gap penalties and weight matrix choice. Nucleic Acids Symposium Series. 22: 4673-4680. 
Türktaş M, Aslay M, Kaya E and Ertuğrul F 2012. Molecular characterization of phylogenetic relationships in Fritillaria species inferred from chloroplast $t r n \mathrm{~L}-t r n \mathrm{~F}$ sequences. Turk J. Biol. 36: 552-560.

Uzun A, Ozongun S, Gulsen O, Y1lmaz KU, Kaymak S and Ercisli S 2016. Determination of genetic relatedness among Turkish apple germplasm based on ISSR markers. J. Appl. Bot. Food Qual. 89:82-88

Weiguo Z, Yile P, Zhang S, Miao X and Huang Y 2005. Phylogeny of the genus Morus (Urticales: Moraceae) inferred from ITS and trnL-F sequences. Afr. J. Biotechnol. 4(6): 563-569.

Wolfe KL and Liu RH 2003. Apple peels as a value-added food ingredient. JAgr Food Chem. 51: 1676-1683.

Wolfe KL, Wu X and Liu RH 2003. Antioxidant activity of apple peels. J. Agr. Food Chem. 51: 609-614.

(Manuscript received on 9 July, 2018; revised on 18 January, 2019) 